Vol. 1 No. 2 Oktober 2021 e-ISSSN : 2797-0159 | p-ISSN : 2797-0574

\title{
SOSIALISASI PENDIDIKAN INKLUSIF DALAM RANGKA MENINGKATKAN KOMPETENSI GURU PENDIDIKAN ANAK USIA DINI
}

\author{
NURAENI, I MADE SONNY GUNAWAN \\ Bimbingan dan Konseling, FIPP Universitas Pendidikan Mandalika \\ Email: nuraeni@undikma.ac.id
}

\begin{abstract}
ABSTRAK
Tujuan dilakukannya kegiatan pengabdian masyarakat ini adalah untuk meningkatkan pemahaman guru akan peran dan fungsinya menjadi seorang pendidik di sekolah inklusif. Kegiatan pengabdian masyarakat ini dilaksanakan dengan melakukan sosialisasi layanan informasi kepada para guru pendidikan anak usia dini se-kota Mataram. Melalui kegiatan ini diharapkan para guru pendidikan anak usia dini dapat mengoptimalkan perannya di sekolah dalam membantu siswa atau anak usia dini mengembangkan potensinya sesuai dengan tahaptahap perkembangannya. Kegiatan pengabdian masyarakat ini dilakukan dengan memberikan sosialisasi berupa layanan informasi kepada para guru-guru pendidikan anak usia dini (PAUD) di Kota Mataram. Peserta di dalam kegiatan pengabdian masyarakat ini berjumlah 80 orang guru PAUD. Hasil dari pengabdian masyarakat ini menunjukkan partisipasi aktif dari guru-guru PAUD, di mana dapat terlihat dari banyaknya pertanyaan yang diajukan kepada narasumber. Lebih lanjut, untuk melihat keefektifan dari kegiatan sosialisasi maka dilakukan proses wawancara secara acak kepada beberapa guru PAUD di Kota Mataram dan hasilnya adalah beberapa guru sudah mampu untuk menyesuaikan proses pembelajaran yang dilakukan dengan kebutuhan siswa.
\end{abstract}

Kata kunci: Sosialisasi, inklusif, kompetensi, anak usia dini

\section{PENDAHULUAN}

Pendidikan inklusif merupakan suatu strategi untuk mentransformasikan sistem pendidikan yang responsif terhadap beragam kebutuhan dari peserta didik. Menurut Nasichin (2001) pendidikan inklusi adalah pendidikan yang mengikutsertakan anak-anak yang berkebutuhan khusus untuk belajar bersama-sama dengan anak-anak normal sebayanya di sekolah umum sehingga tercipta suasana belajar yang kondusif. Pada prinsipnya sekolah inklusi menyertakan seluruh anak-anak untuk dapat belajar bersama, meski memiliki beberapa kesulitan atau perbedaan-perbedaan tertentu.

Dalam hal ini semua anak memiliki hak dan kesempatan yang sama untuk memperoleh manfaat yang maksimal dari pendidikan. Hak dan kesempatan itu tidak dibedakan oleh keragaman karakteristik individu secara fisik, mental, sosial, emosional, dan bahkan status sosial ekonomi. Inklusif bukan hanya bagi mereka yang berkelainan atau luar biasa melainkan berlaku untuk semua anak. Pendidikan inklusif hanya merupakan salah satu model penyelenggaraan pendidikan bagi anak berkebutuhan khusus. Adapun pendidikan inklusif merupakan perkembangan baru dari pendidikan terpadu. Pada dasarnya di sekolah inklusif setiap anak sesuai dengan kebutuhan khususnya, diusahakan untuk dapat dilayani secara optimal dengan melakukan berbagai modifikasi atau penyesuaian, mulai dari kurikulum, sarana prasarana, tenaga pendidik dan kependidikan, sistem pembelajaran sampai pada sistem penilaiannya.

Dengan kata lain pendidikan inklusif mensyaratkan pihak sekolah yang harus menyesuaikan dengan tuntutan kebutuhan individu peserta didik, bukan peserta didik yang menyesuaikan dengan sistem persekolahan. Keuntungan dari pendidikan inklusif adalah anak berkebutuhan khusus maupun anak biasa dapat saling berinteraksi secara wajar sesuai dengan tuntutan kehidupan sehari-hari di masyarakat, dan kebutuhan pendidikannya dapat terpenuhi sesuai potensinya masing-masing. Konsekuensi penyelenggaraan pendidikan inklusif adalah pihak sekolah dituntut melakukan berbagai perubahan, mulai cara pandang, sikap, sampai pada proses pendidikan yang berorientasi pada kebutuhan individual tanpa diskriminasi. 
Masalah yang banyak terjadi di sekolah-sekolah inklusif adalah guru tidak paham akan tugas dan fungsinya yang sedikit berbeda dengan guru pada umunya. Hal ini juga banyak terjadi pada guru-guru pendidikan anak usia dini di satuan pendidikan PAUD yang ada di Kota Mataram. Pada dasarnya tugas guru yang paling utama dalam hal ini adalah mengajar dan mendidik. Sebagai pengajar ia merupakan perantara aktif antara siswa dan ilmu pengetahuan, sedang sebagai pendidik ia merupakan perantara aktif dalam mengembangkan pribadi siswa serta mendekatkan mereka dengan pengaruh dari luar yang baik (Hidayat, 2009). Dengan demikian seorang guru wajib memiliki segala sesuatu yang erat hubungannya dengan bidang tugasnya, yaitu pengetahuan, sifat-sifat kepribadian, serta kesehatan jasmani dan rohani.

Ada tiga kemampuan yang harus dimiliki oleh guru yang ungul dan tangguh di sekolah inklusif, yaitu: Pertama, general ability adalah religious dan berkepribadian, memiliki sikap dan kemampuan mengaktualisasikan diri, serta memiliki sikap dan kemampuan mengakui dan menghargai keberagaman peserta didik. Kedua, basic ability adalah mampu mengidentifikasi anak berkebutuhan khusus, memahami konsep dan mampu merancang, melaksanakan, dan mengevaluasi pembelajaran bagi anak berkebutuhan khusus, mampu memberikan layanan bimbingan dan konseling anak berkebutuhan khusus, mampu mengembangkan kurikulum sesuai dengan kemampuan dan kebutuhan anak berkebutuhan khusus. Ketiga, specific ability adalah mampu melakukan modifikasi perilaku, menguasai konsep dan keterampilan pembelajaran bagi anak yang mengalami gangguan/kelainan penglihatan, menguasai konsep dan keterampilan pembelajaran bagi anak yang mengalami gangguan/kelainan pendengaran/komunikasi, menguasai konsep dan keterampilan pembelajaran bagi anak yang mengalami gangguan/kelainan intelektual dan lamban belajar menguasai konsep dan keterampilan pembelajaran bagi anak yang mengalami gangguan/kelainan anggota tubuh dan gerakan, menguasai konsep dan keterampilan pembelajaran bagi anak yang mengalami gangguan/kelainan perilaku dan sosial dan menguasai konsep dan keterampilan pembelajaran bagi anak yang mengalami kesulitan belajar.

\section{METODE PELAKSANAAN}

Sebagai solusi dari permasalahan yang dihadapi oleh guru-guru pendidikan anak usia dini yang ada di Kota Mataram dalam meningkatkan pemamahaman mereka tentang tugas dan fungsi guru di sekolah inklusif, maka dapat diterapkan beberapa metode kegiatan yaitu:

1. Rencana Kegiatan

Kegiatan pengabdian masyarakat ini dilakukan dengan memberikan sosialisasi berupa layanan informasi terhadap guru-guru pendidikan anak usia dini di Kota Mataram yang berjumlah 80 orang. Dalam kegiatan pengabdian masyarakat ini mitra memfasilitasi segala keperluan yang dibutuhkan untuk kelancaran kegiatan. Kegiatan pengabdian masyarakat ini bertempat di Kator Dinas Pendidikan Kota Mataram yang berlangsung selama 3 jam.

2. Implementasi Kegiatan

Sebelum kegiatan pengabdian berupa penyampaian informasi tentang tugas dan fungsi guru di sekolah inklusif dilakukan, Tim Pengabdian Masyarakat mengumpulkan data terkait kebutuhan guru pendidikan anak usia dini di sekolah inklusif yang ada di Kota Mataram. Dari hasil needs assessment tersebut TIM memutuskan untuk memberikan layanan informasi dengan tema "peran dan fungsi guru di sekolah inklusif". Kegiatan ini dilakukan untuk memberikan pemahaman kepada guru pendidikan anak usia dini akan peran dan fungsinya di sekolah inklusif sehingga dapat menyesuaikan diri dengan kebutuhan siswa yang memiliki kebutuhan khusus. Metode yang digunakan dalam kegiatan pengabdian ini berupa penyampaian informasi dengan teknik ceramah dan diskusi yang dipadukan menggunakan media pembelajaran berupa video edukasi sehingga dapat memotivasi minat para guru pendidikan anak usia dini untuk lebih memahami materi yang disampaikan. Penyampaian materi dilakukan oleh Tim Dosen Fakultas Ilmu Pendidikan dan Psikologi Universitas Pendidikan Mandalika yang diketuai oleh Ibu Nuraeni, M.Si 
yang berperan sebagai Keynote Speaker dan Bapak Dr. I Made Sonny Gunawan, M.Pd., sebagai anggota yang bertugas sebagai Narasumber pendamping.

3. Evaluasi Kegiatan

Kegiatan pengabdian masyarakat ini di evaluasi tingkat keberhasilannya dengan melakukan wawancara langsung terhadap guru-guru pendidikan anak usia dini yang berada di sekolah inklusif Kota Mataram.

\section{HASIL DAN PEMBAHASAN}

Pelaksanaan kegiatan pengabdian masyarakat ini dilakukan pada 18 November 2021 di kantor Dinas Pendidikan Kota Mataram. Sasaran utama dalam kegiatan pengabdian ini adalah guru-guru pendidikan anak usia dini yang berada di Kota Mataram. Kegiatan pengabdian masyarakat ini berupa sosialisasi dengan memberikan layanan informasi terkait peran dan fungsi guru di sekolah inklusif. Tujuan dari kegiatan pengabdian ini adalah untuk meningkatkan pemahaman guru akan peran dan fungsinya menjadi seorang pendidik di sekolah inklusif sehingga dapat menyesuaiakan metode pembelajaran dengan kebutuhan siswa yang memiliki kebutuhan khusus.

Kegiatan sosialisasi berupa layanan informasi terkait dengan peran dan fungsi guru di sekolah inklusif berjalan dengan lancar dan penuh antusias dari para peserta yang mengikuti kegiatan. Banyak dari para peserta kegiatan yang mengajukan pertanyaan-pertanyaan terkait materi yang disampaikan karena menganggap hal itu penting untuk ditanyakan sehingga mendapatkan kejelasan dan informasi baru terkait dengan tugas dan fungsinya di sekolah inklusif. Selama proses kegiatan berlangsung ada sekitar 8 orang yang mengajukan pertanyaan pada sesi pertama dan 4 orang pada sesi kedua. Adapun suasana dalam kegiatan dikusi tersebut sangat aktif karena banyak dari para peserta juga yang memberikan masukan dan saran dari pertanyaan-pertanyaan yang telah diajukan. Agar lebih jelas kegiatan pengabdian ini ditunjukkan melalui gambar 1.
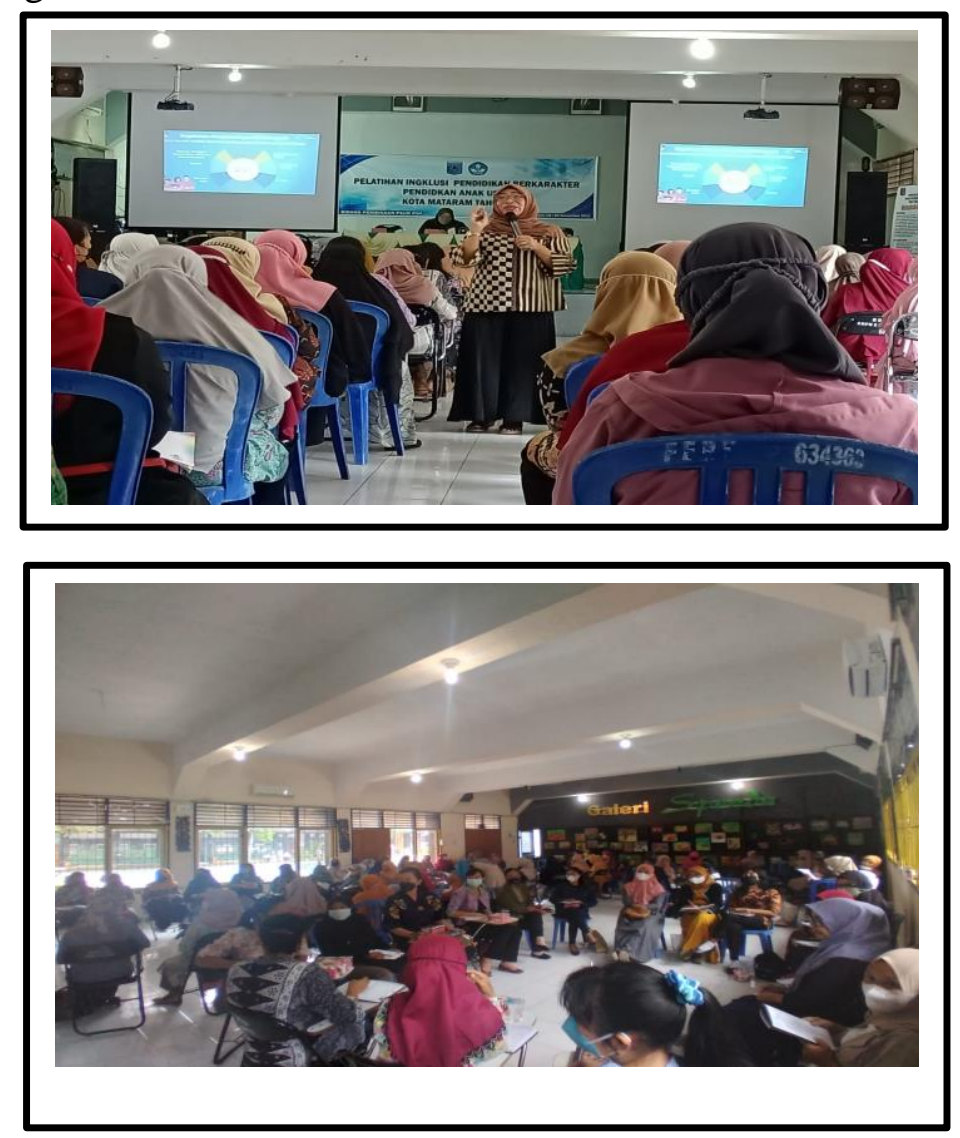

Gambar 1. Foto Kegiatan Pengabdian Masyarakat 
Pendidikan inklusif pada hakikatnya merupakan hak asasi dalam memperoleh pendidikan yang layak dan sangat baik untuk meningkatkan toleransi sosial. Secara sederhana ada beberapa hal yang dapat dipertimbangkan, antara lain: (1) Semua anak memiliki hak untuk belajar secara bersama-sama, (2) Keberadaan anak-anak jangan didiskriminasikan, dipisahkan, dikucilkan karena kekurangmampuan atau mengalami kesulitan dalam pembelajaran, dan (3) Tidak ada satupun ketentuan untuk mengucilkan anak dalam pendidikan. Lebih lanjut, pendidikan inklusif merujuk pada pendidikan untuk semua yang berusaha menjangkau semua orang tanpa kecuali.

Perubahan pendidikan melalui pendidikan inklusif memiliki arti penting khususnya dalam kerangka pengembangan pendidikan bagi anak berkebutuhan khusus. Secara teoritis pendidikan inklusif adalah proses pendidikan yang memungkinkan semua anak berkesempatan untuk berpartisipasi secara penuh dalam kegiatan kelas reguler, tanpa memandang kelainan, ras, atau karakteristik lainnya. Pendidikan inklusif dapat diikuti oleh anak berkelainan tingkat ringan, sedang dan berat secara penuh di kelas reguler. Hal ini menunjukan bahwa kelas inklusi merupakan kelas yang sesuai bagi anak berkelainan apapun jenis kelainan dan bagaimanapun gradasinnya (Widyastono, 2004). Lebih lnjut, landasan filosofis utama dari penerapan pendidikan inklusif di Indonesia adalah Pancasila yang merupakan lima pilar sekaligus cita-cita yang didirikan atas fondasi yang lebih mendasar lagi, yang disebut Bhineka Tunggal Ika (Bintoro, 2004).

Menurut Irvan (2017) terdapat tiga jenis tenaga pendidik di sekolah inklusi, antara lain: (1) Guru kelas yang merupakan pendidik/pengajar pada kelas tertentu di sekolah inklusi; (2) Guru mata pelajaran merupakan guru yang mengajar mata pelajaran tertentu sesuai kualifikasi yang dipersyaratkan; dan (3) Guru pendamping khusus merupakan guru yang memiliki kompetensi sekurang-kurangnya S1 Pendidikan Luar Biasa dan atau Kependidikan yang memiliki kompetensi pendidikan khusus dengan tuntuan profesi yang berfungsi sebagai pendukung guru reguler dalam memberikan pelayanan pendidikan khusus, intervensi kompensatoris, sesuai kebutuhan peserta didik berkebutuhan khusus di sekolah inklusi. Dengan demikian seorang guru wajib memiliki segala sesuatu yang erat hubungannya dengan bidang tugasnya, yaitu pengetahuan, sifat-sifat kepribadian, serta kesehatan jasmani dan rohani.

Kebermanfaan dari pengabdian ini dapat di lihat melalui hasil tanya jawab atau diskusi selama kegiatan sosialisasi berlangsung. Adapun hasil yang diperoleh selama kegiatan ini berlangsung yaitu dapat meningkatkan pemahaman para guru pendidikan anak usia dini di dalam menyiapakan bahan ajar, penggunaan metode pembelajaran yang sesuai dengan kebutuhan anak dan menciptakan sekolah yang ramah bagi anak berkebutuhan khusus. Adapun sekolah yang ramah adalah sekolah yang mengerti bahwa tujuan pendidikan adalah sama untuk semua, yaitu semua murid mempunyai hak untuk merasa aman dan nyaman, untuk mengembangkan diri, untuk membuat pilihan, untuk berkomunikasi, untuk menjadi bagian dari komunitas, untuk mampu hidup dalam situasi dunia yang terus berubah, untuk menghadapi banyak transisi dalam hidup, dan untuk memberi kontribusi yang bernilai (Rahim, 2016).

Selain itu para guru dalam hal ini harus bisa menjadi fasilitator dan motivator bagi para siswa di sekolah. Nuraeni (2021) mengungapkan bahwa guru pendidikan anak usia dini harus memiliki etos kerja yang unggul sehingga dapat melayani peserta didik atau siswa dengan baik sesuai dengan kebutuhannya. Menurut Sinarmo (2010) ada delapan etos kerja unggulan yang perlu dipahami, yang dapat dikembangkan oleh guru dalam bertugas. Etos kerja tersebut sebagai berikut: (1) kerja itu suci, kerja adalah panggilanku, aku sanggup bekerja benar; (2) kerja itu sehat, kerja adalah aktualisasiku, aku sanggup bekerja keras; (3) kerja itu rahmat, kerja adalah terima kasihku, aku sanggup bekerja tulus; (4) kerja itu amanah, kerja itu tanggungjawabku, aku sanggup bekerja tuntas; (5) kerja itu seni atau permainan, kerja adalah kesukaanku, aku sanggup kerja kreatif; (6) kerja itu ibadah, kerja adalah pengabdianku, aku sanggup bekerja serius; (7) kerja itu mulia, kerja adalah pelayananku, aku sanggup bekerja sempurna; dan (8) kerja itu kehormatan, kerja adalah kewajibanku, aku sanggup bekerja unggul. Dalam hal ini maka dapat disimpulkan bahwa guru pendidikan anak usia dini harus memiliki 
delapan etos kerja tersebut agar dapat dengan sepenuh hati melayani siswa yang memiliki kebutuhan khusus di sekolah inklusif.

\section{KESIMPULAN}

Berdasarkan uraian pelaksanaan kegiatan pengbadian masyarakat di atas maka ada beberapa hal yang dapat disimpulkan adalah sebagai berikut: (1) kegiatan pengabdian masyarakat ini dapat meningkatkan pemahaman guru pendidikan anak usia dini tentang peran dan fungsinya di dalam sekolah inklusif; dan (2) para guru pendidikan anak usia dini yang berada di sekolah inklusif harus dapat menyesuaikan dengan tuntutan kebutuhan individu peserta didik, bukan peserta didik yang menyesuaikan dengan sistem persekolahan.

\section{DAFTAR PUSTAKA}

Bintoro, T. (2004). Pendidikan Inklusi. Republika Online: http://www.republika.co.id Hidayat. (2009). Pengenalan dan identifikasi anak berkebutuhan khusus dan strategi pembelajarannya. Balikpapan: Kegiatan Workshop.

Irvan, M. (2017). Pengetahuan mahasiswa PG-PAUD UNIPA Surabaya tentang pendidikan inklusif. Jurnal Buana Pendidikan, 24, 1, 155-164.

Nasichin. (2001). Kebijakan Direktorat Pendidikan Luar Biasa. Jurnal Rehabilitasi dan Remedial, 2, 1, 1-8.

Nuraeni. (2021). Korelasi antara etika dengan etos kerja pendidik PAUD. Cendekia: Jurnal Ilmu Pengetahuan, 1, 3, 208-212.

Rahim, A. (2016). Pendidikan inklusif sebagai strategi dalam mewujudkan pendidikan untuk semua. Trihayu: Jurnal Pendidikan Pendidikan Ke-SD-an, 3, 1, 68-71.

Sinarmo, J. (2010). Delapan Etos Kerja Keguruan. Jakarta: Institut Darma Mahardika.

Widyastono, H. (2004). Penyelenggaraan pendidikan inklusif bagi anak berkelainan. Jurnal Pendidikan Dan Kebudayaan 46, 1, 1-8. 